\title{
Phytochemical profile, antioxidant, antimicrobial and antipancreatic lipase activities of fermented Camellia japonica L leaf extracts
}

\author{
Seo Hyun Moon', Min Young Kim ${ }^{2 *}$ \\ ${ }^{1}$ Department of Forensic DNA, National Forensic Service, Wonju, Gangwon-do, ${ }^{2}$ Toxicology Laboratory, Faculty of \\ Biotechnology (Biomaterials), College of Applied Life Science, SARI, Jeju National University, Jeju, Republic of Korea \\ *For correspondence: Email: jeffmkim@jejunu.ac.kr; Tel: +82-64-754-3349
}

Sent for review: 9 January 2018

Revised accepted: 23 April 2018

\begin{abstract}
Purpose: To investigate the probable antioxidant, antimicrobial and antipancreatic lipase effects of fermented Camellia japonica leaf extracts.

Methods: Camellia japonica leaves fermented with Nuruk were extracted using methanol and ethanol. Total phenolic, flavonoid, carotenoid and L-ascorbic acid contents were determined by UV-visible spectrophotometry. The antioxidant activities of these extracts were determined by free radical scavenging, ferrous ion chelating and reducing power assays. Their antimicrobial properties against Gram-positive Staphylococcus epidermidis and Bacillus subtilis, and Gram-negative Klebsiella pneumonia and Escherichia coli bacteria were evaluated by disc diffusion method. Inhibition of pancreatic lipase was measured based on the hydrolytic reaction of p-nitrophenyl butyrate with pancreatic lipase.

Results: The ethanol extracts of fermented Camellia japonica leaves exhibited higher phenolic (32274 $\mathrm{mg} \mathrm{GAE} / 100 \mathrm{~g})$ and flavonoid (20519 $\mathrm{mg} R E / 100 \mathrm{~g})$ contents with higher superoxide $\left(\mathrm{IC}_{50}=0.23\right.$ $\mathrm{mg} / \mathrm{mL}$ ), hydrogen peroxide $\left(I C_{50}=0.28 \mathrm{mg} / \mathrm{mL}\right.$ ) radical scavenging and ferrous ion chelating $\left(I C_{50}=\right.$ $0.21 \mathrm{mg} / \mathrm{mL}$ ) activities than those of methanol. These ethanol extracts also showed higher antimicrobial activities against all bacterial strains tested with higher inhibitory effects on pancreatic lipase than methanol extracts.

Conclusion: The results highlight the possible use of fermented Camellia japonica leaf extracts as a source of antioxidant, antibacterial and antiobesity agents. Ethanol is recommended as solvent for extracting antioxidants, antibacterial and antiobesity agents from this plant.
\end{abstract}

Keywords: Antioxidant activity, Antimicrobial activity, Fermented Camellia japonica extracts, Pancreatic lipase inhibition

This is an Open Access article that uses a funding model which does not charge readers or their institutions for access and distributed under the terms of the Creative Commons Attribution License (http://creativecommons.org/licenses/by/4.0) and the Budapest Open Access Initiative (http://www.budapestopenaccessinitiative.org/read), which permit unrestricted use, distribution, and reproduction in any medium, provided the original work is properly credited.

Tropical Journal of Pharmaceutical Research is indexed by Science Citation Index (SciSearch), Scopus, International Pharmaceutical Abstract, Chemical Abstracts, Embase, Index Copernicus, EBSCO, African Index Medicus, JournalSeek, Journal Citation Reports/Science Edition, Directory of Open Access Journals (DOAJ), African Journal Online, Bioline International, Open-J-Gate and Pharmacy Abstracts

\section{INTRODUCTION}

Tea is a commonly consumed beverage worldwide due to its health benefits for human consumption. Most commercially prepared tea is obtained from differential preparation of Camellia sinensis (L.) Kuntze (apical buds and terminal leaves) [1]. Methods for obtaining $C$. sinensis 
teas can be classified into non-fermented (green and white teas), semi-fermented (oolong and red teas) and fully fermented (black and pu-erh teas) [1]. Fully-fermented tea is fermented by microorganisms such as Aspergillus, Penicillium, Rhizopus, and yeast that determine its taste, color and fragrance as well as functional components [2-4]. In fermentation processes, monomeric catechins are oxidized by polyphenol oxidase leading to dimers and polymers such as theaflavin, thearubigin, and gallic acid [5]. These components are responsible for the dark coloration, lack of bitterness and health benefit of fermented teas.

Camellia japonica $\mathrm{L}$. is a tree belonging to Theaceae family. It has been used in folk medicine in Korea [6]. Extensive studies have been made on constituents of Camellia japonica, including saponins in its fruits and seeds and triterpenes in its flowers and seed oil [6-8]. It has been reported that leaves of Camellia japonica possess antioxidant, antifungal, and cytotoxic properties [9-11].

Nuruk is a Korean traditional starter made from rice, corn or wheat fermented by various microorganisms such as fungi, yeast and lactic acid bacteria at low temperature with long periods. It has been used for Korean fermented food [12]. Many studies have been undertaken to investigate physiological activities of fullyfermented tea manufactured by using Aspergillus and Rhizopus. However, physiological and biochemical features of fully-fermented tea manufactured using Nuruk has not fully characterized yet. Therefore, the objective of this study was to evaluate antioxidant, antimicrobial and antipancreatic lipase properties of methanol and ethanol extracts of Camellia japonica leaves fermented with Nuruk as well as their bioactive contents including total flavonoids, total carotenoids, and L-ascorbic acid.

\section{EXPERIMENTAL}

\section{Fermentation of Camellia japonica leaves and sample preparation}

Young leaves (third to fifth leaves from the top; light green) of Camellia japonica L. were harvested in May 2016 from Seogwipo-si, Jeju Island, South Korea and a voucher specimen (no. KCJYL-20160521) has been deposited in the herbarium of College of Applied Life Science, Jeju National University. Young leaves of Camellia japonica L. were identified by Professor Jung Hyun Kim from Cheju Tourism College. Young leaves of Camellia japonica L. were used in the fermentation process using a previously described protocol [4] with some modification. Briefly, $1 \mathrm{~kg}$ of fresh picked young leaves of Camellia japonica were washed and soaked in tap water for $2 \mathrm{~h}$. After draining the water, soaked leaves were steamed for $1 \mathrm{~h}$. A traditional wheat-based nuruk was crushed and mixed with distilled water, followed by incubation at $60-62{ }^{\circ} \mathrm{C}$ for $5 \mathrm{~h}$. After centrifugation, $100 \mathrm{~mL}$ of the resulting supernatant was added to steamed leaves, mixed well and transferred to a fermentation container. This mixture was then incubated at $50{ }^{\circ} \mathrm{C}$ for two weeks. Freeze-dried powder $(200 \mathrm{~g})$ of fermented Camellia japonica leaves was extracted with $1 \mathrm{~L}$ of $100 \%$ methanol or $70 \%$ ethanol at $25{ }^{\circ} \mathrm{C}$ for $72 \mathrm{~h}$ with constant shaking. The extract was then purified using a filter system (Corning, NY, USA), concentrated using a rotary evaporator (Buchi Rotavapor R200, New Castle, DE, USA), freeze dried, and stored at $-20 \stackrel{\circ}{\circ} \mathrm{C}$ until further use. These dried extracts were reconstituted in dimethyl sulfoxide (DMSO, Amresco, Solon, Ohio, USA). DMSO acts as a solvent without changing any property of methanol or ethanol extracts.

\section{Analysis of total phenolic and flavonoid contents}

Contents of total phenolics and flavonoids were determined with published method [13]. For total phenol quantitation, $30 \mu \mathrm{L}$ of methanol or ethanol extracts of fermented Camellia japonica leaves was thoroughly mixed with $30 \mu \mathrm{L}$ of $95 \%$ ethanol, $150 \mu \mathrm{L}$ of distilled water, $15 \mu \mathrm{L}$ of FolinCiocalteu reagent and $30 \mu \mathrm{L}$ of saturated sodium carbonate solution (5\%). After $60 \mathrm{~min}$ of standing at room temperature, the absorbance was read at $725 \mathrm{~nm}$ against a blank in a Spectra MR microplate reader (Dynex Technologies, Inc., Chantilly, VA, US). Content of total phenolics was calculated based on gallic acid calibration curves. It was expressed as $\mathrm{mg}$ gallic acid per $100 \mathrm{~g}$ dry matter. To determine total flavonoids, each extract $(15 \mu \mathrm{L})$ was mixed with $4.5 \mu \mathrm{L}$ of $5 \% \mathrm{NaNO}_{2}, 60 \mu \mathrm{L}$ of distilled water and $4.5 \mu \mathrm{L}$ of $10 \% \mathrm{AlCl}_{3}$. After incubation at room temperature for $6 \mathrm{~min}, 60 \mu \mathrm{L}$ of $\mathrm{NaOH}$ solution $(4 \%)$ was added to the mixture to reach a final volume of $150 \mu \mathrm{L}$ with distilled water. The absorbance was measured $15 \mathrm{~min}$ later at $510 \mathrm{~nm}$. Quantitative determination of total flavonoids (mg rutin/100 g) was done based on a standard curve of rutin.

\section{Evaluation of total carotenoid content}

An aliquot of the extracts was used for quantification of total carotenoid content using a Spectra MR microplate reader (Dynex Technologies, Inc., Chantilly, VA, USA). Total carotenoid content was calculated by measuring 
the absorbance at 470, 653 and $666 \mathrm{~nm}$. It was expressed as mg/100 g [14]. All operations were carried out on ice under dim light to prevent photodegradation, isomerizations, or structural changes of carotenoids.

\section{Determination of ascorbic acid content}

Ascorbic acid content of the extracts was determined following published procedures [15] with some modifications. Briefly, the extract $(0.15$ g) was treated with $10 \mathrm{~mL}$ of $1 \%$ metaphosphoric acid $(\mathrm{pH} 1.86)$ in a rotary mixer at $200 \mathrm{rpm}$ for 45 $\mathrm{min}$ in the dark. After centrifuging at $1600 \times \mathrm{g}$ for 15 min at $4^{\circ} \mathrm{C}$, the supernatant was collected. A portion $(25 \mu \mathrm{L})$ of the supernatant was mixed with $225 \mu \mathrm{L}$ of 2 , 6-dichloroindophenol (0.3 $\mathrm{mg} / \mathrm{mL}$ ), and the absorbance was measured at $515 \mathrm{~nm}$ within $15 \mathrm{~s}$. The content of ascorbic acid (mg AA/100 g) was calculated based on the calibration curve of authentic L-ascorbic acid (0.0125-1 mM).

\section{2,2-Diphenyl-1-pycryl-hydrazyl (DPPH) free radical scavenging assay}

DPPH radical scavenging assay was conducted with published method [13]. Briefly, $100 \mu \mathrm{L}$ of fermented Camellia japonica leaf extracts at various concentrations was prepared in 96-well plates and equal volume of $0.4 \mathrm{mM}$ DPPH was added to each well. The solution was kept in the dark for $10 \mathrm{~min}$ at room temperature and the absorbance of the solution was measured at 517 $\mathrm{nm}$ using a Spectra MR microplate reader (Dynex Technologies, Inc, Chantilly, VA, USA).

\section{Superoxide radical scavenging assay}

Superoxide anion scavenging capacity of fermented Camellia japonica leaf extracts was analyzed by estimating the reduction product of nitroblue tetrazolium (NBT), as described previously [14]. The reaction mixture contained $50 \mathrm{mM} \mathrm{Na}{ }_{2} \mathrm{CO}$ buffer, $3 \mathrm{mM}$ xanthine, $3 \mathrm{mM}$ ethylenediamine tetraacetic acid, $0.5 \mathrm{mM}$ NBT and bovine serum albumin solution. Test extracts were added to the reaction mixture and incubated at $25^{\circ} \mathrm{C}$ for $10 \mathrm{~min}$. The reaction was started by adding xanthine oxidase (XO) (0.25 units $/ \mathrm{mL})$. After incubation at $25^{\circ} \mathrm{C}$ for another $25 \mathrm{~min}$, absorbance was recorded at $560 \mathrm{~nm}$ using an ELISA reader, against blank samples, which did not contain XO enzyme.

\section{Hydrogen peroxide radical scavenging assay}

The hydrogen peroxide scavenging activity of methanol or ethanol extract of the fermented
Camellia japonica leaves was measured using a previous method [14].

\section{Nitric oxide radical scavenging assay}

Nitric oxide scavenging assay was performed by published method described by $\mathrm{Im}$ et al [14]. Briefly, the reaction mixture $(100 \mu \mathrm{L})$ containing $10 \mathrm{mM}$ sodium nitroprusside in phosphatebuffered saline $(\mathrm{pH} 7.0)$, with or without of fermented Camellia japonica leaf extracts at concentrations of $0.125,0.25,0.5,1$ and 2 $\mathrm{mg} / \mathrm{mL}$, was incubated at $25^{\circ} \mathrm{C}$ for $3 \mathrm{~h}$. After the ncubation, reaction mixture was mixed with an equal amount of Greiss reagent (1 \% sulfanilamide and $0.1 \% \mathrm{~N}-1$-naphthylethylene diamine dihydrochloride in $2.5 \%$ polyphosphoric acid) and, incubated at $25^{\circ} \mathrm{C}$ for another $5 \mathrm{~min}$ and the absorbance at $540 \mathrm{~nm}$ was then measured using a Spectra MR microplate reader (Dynex Technologies, Inc., Chantilly, VA, USA).

\section{Ferrous ion chelating assay}

The chelating ability was determined according to the method of Im et al [14]. An aliquot of 250 $\mu \mathrm{L}$ of each methanol and ethanol extract of fermented Camellia japonica leaves was mixed with $5 \mu \mathrm{L}$ of $2 \mathrm{mM}$ ferrous chloride $\left(\mathrm{FeCl}_{2}\right)$. The reaction was initiated by adding $10 \mu \mathrm{L}$ of $5 \mathrm{mM}$ ferrozine. After $10 \mathrm{~min}$ of incubation at room temperature, the absorbance was determined at $562 \mathrm{~nm}$ using a microplate reader.

\section{Reducing power assay}

Reducing power assay was carried out as described previously by Huang et al [16]. The methanol and ethanol extract solutions (concentration range 12.5 to $200 \mu \mathrm{g} / \mathrm{mL}$ ) were mixed with $200 \mathrm{mM}$ sodium phosphate buffer $(\mathrm{pH}$ 6.6) containing $1 \%(\mathrm{w} / \mathrm{v})$ potassium ferricyanide. After the mixture was incubated at $50{ }^{\circ} \mathrm{C}$ for 20 $\min , 10 \%(\mathrm{w} / \mathrm{v})$ trichloroacetic acid was added. The mixture was then added into each well of a 96-well plate, and the absorbance was measured at $700 \mathrm{~nm}$. $I_{50}$ value $(\mathrm{mg} / \mathrm{mL})$, the effective concentration at which the absorbance was 0.5 for reducing power, was obtained by interpolation from linear regression analysis.

\section{Evaluation of antimicrobial activity}

Bacterial strains used in this study included Staphylococcus epidermidis, Bacillus subtilis, Klebsiella pneumonia, Escherichia coli. They were kindly provided by Prof. Ju Sung Kim (Jeju National University). Sterilized nutrient broth was inoculated with the test bacteria and incubated at $37^{\circ} \mathrm{C}$ overnight. Disc diffusion assay was carried 
out to detect the antimicrobial activity of fermented Camellia japonica leaf extracts using published method $[17,18]$ with slight modification. Briefly. discs $(8.0 \mathrm{~mm})$ were overlaid with fermented Camellia japonica leaf extracts overnight and then dried overnight in a drying oven at $40{ }^{\circ} \mathrm{C}$. Discs were placed on agar medium and incubated at $37^{\circ} \mathrm{C}$ for $12-18 \mathrm{~h}$. Antimicrobial activity was determined by calculating the diameter of the growth inhibition zone $(\mathrm{mm})$ around the disc. Effects were compared with that of standard antibiotic ampicillin (10 $\mu \mathrm{g} /$ disc). Vehicle (DMSO) alone served as negative control.

\section{Pancreatic lipase inhibitory assay}

Lipase inhibitory activity of fermented Camellia japonica leaf extract was estimated based on ability to inhibit in vitro porcine pancreatic lipase activity as described previously [19] with slight modifications. Briefly, the reaction mixture consisted of $6 \mu \mathrm{L}$ of $10 \mathrm{mg} / \mathrm{mL}$ of porcine pancreatic lipase and $170 \mu \mathrm{L}$ of Tris buffer. Then $20 \mu \mathrm{L}$ of fermented Camellia japonica leaf extract was added and incubated at $37^{\circ} \mathrm{C}$ for $15 \mathrm{~min}$. Four microliters of $10 \mathrm{~m}$ Mp-NPB was then added and incubated at $37^{\circ} \mathrm{C}$ for $60 \mathrm{~min}$.

Lipase activity was determined by measuring the hydrolysis of $p$-NPB to p-nitrophenol at $400 \mathrm{~nm}$ using a Spectra MR microplate reader (Dynex Technologies, Inc., Chantilly, VA, USA). $I_{50}$, the concentration of a tested compound showing 50 $\%$ inhibition of the enzyme activity, was evaluated from the least square regression line of logarithmic concentration plotted against inhibitory activity. Hesperidin was used as a positive control [19].

\section{Statistical analysis}

Results ware expressed as mean \pm standard deviation (SD) of triplicate values. They were analyzed with SPSS version 12.0 using a nonparametric test (Mann-Whitney $U$ test). A dose response curve was plotted to determine $I_{50}$ values, defined as the concentration sufficient to obtain $50 \%$ of the maximum scavenging capacity. Correlations among data obtained were analyzed using Pearson's correlation coefficient. Significant difference was considered at $p<0.05$.

\section{RESULTS}

\section{Contents of total phenol, total flavonoid, total carotenoid, and L-ascorbic acid}

Table 1 shows total phenolic, flavonoid, carotenoid and L-ascorbic acid contents in methanol and ethanol extracts of fermented Camellia japonica leaves. Contents of total phenols and flavonoids were significantly higher in ethanol extract (32274 and $20519 \mathrm{mg}$ GAE/100 g, respectively) than those in methanol extract (27791 and $19273 \mathrm{mg}$ GAE/100 g, respectively) $(p<0.05)$. However, methanol extract of fermented Camellia japonica leaves contained higher total carotenoids and L-ascorbic acid contents than ethanol extract $(p<0.05)$ (Table 1).

\section{Antioxidant activities}

Ethanol extracts of fermented Camellia japonica leaves exhibited significantly higher superoxide and hydrogen peroxide scavenging activities than methanol extracts $(p<0.05)$ (Table 2). However, methanol and ethanol extracts showed similar scavenging activities for DPPH and nitric oxide radicals (Table 2). Results of metal chelating ability of methanol and ethanol extracts of fermented Camellia japonica leaves are also shown in Table 1.

Chelating abilities of both extracts were increased with increasing in concentration. Metal chelating abilities of methanol and ethanol extracts at concentration of $0.5 \mathrm{mg} / \mathrm{mL}$ of ferrous ions were $85 \%$ and $97 \%$, respectively. The $\mathrm{IC}_{50}$ value of the chelating effect of methanol extract was $0.28 \mathrm{mg} / \mathrm{mL}$, which was higher than that of ethanol extract $(0.21 \mathrm{mg} / \mathrm{mL})(p<0.05)$ (Table 2). Ethylenediaminetetraacetic acid (EDTA), at $0.5 \mathrm{mg} / \mathrm{mL}$ used as positive control showed $99 \%$ chelating ability on ferrous ion.

Table 1: Total polyphenol, flavonoid, carotenoid and L-ascorbic acid contents in methanol and ethanol extracts of Camellia japonica fermented leaves

\begin{tabular}{lcccc}
\hline Solvent & $\begin{array}{c}\text { Total polyphenol } \\
\text { (mg GAE/100 g) }\end{array}$ & $\begin{array}{c}\text { Total flavonoid } \\
\text { (mg RE/100 g) }\end{array}$ & $\begin{array}{c}\text { Total carotenoid } \\
\text { (mg/100 g) }\end{array}$ & $\begin{array}{c}\text { L-Ascorbic acid } \\
\text { (mg AA/100 g) }\end{array}$ \\
\hline $100 \% \mathrm{MeOH}$ & $27791 \pm 336$ & $19273 \pm 416$ & $1711 \pm 24$ & $491 \pm 31$ \\
$70 \% \mathrm{EtOH}$ & $32274 \pm 240^{\circ}$ & $20519 \pm 291$ & $1586 \pm 15$ & $258 \pm 25$ \\
\hline
\end{tabular}

Abbreviations: GAE = gallic acid equivalent, $\mathrm{RE}=$ rutin equivalent, $\mathrm{AA}=\mathrm{L}$-ascorbic acid. 'Data were statistically different from the value of methanol extract $(p<0.05)$ 
These results suggest that fermented Camellia japonica leaf extracts are capable of scavenging free radicals and preventing harmful effects of free radicals.

Reducing power of fermented Camellia japonica leaf extract was determined using ascorbic acid as a positive control. The reducing ability of extract was increased with increasing concentration. $\mathrm{IC}_{50}$ values of the fermented Camellia japonica leaf extracts were $0.46-0.47$ $\mathrm{mg} / \mathrm{mL}$ (Table 2). The maximum absorbance for crude extract was $0.51-0.52$ at $0.5 \mathrm{mg} / \mathrm{mL}$ compared to 0.64 for ascorbic acid at 0.25 $\mathrm{mg} / \mathrm{mL}$ the positive control.

\section{Correlation between antioxidant components and antioxidant activity}

Knowledge about antioxidant properties and antioxidant components of fermented Camellia japonica leaf extracts is limited. Thus, linear correlation studies were carried out with results obtained from this study. As shown in Table 3, strong correlations between three antioxidant components (total polyphenols, total flavonoids and L-ascorbic acid), and free radicals (DPPH, hydrogen peroxide and nitric oxide) scavenging and chelating activities were found $\left(r^{2}=0.814\right.$ $0.999, p<0.05)$. In addition, total carotenoid was weakly correlated with DPPH and nitric oxide scavenging activity $\left(r^{2}=0.761\right.$ and 0.796 , respectively). On the other hand, all antioxidant components (total polyphenols, total flavonoids, total carotenoids and L-ascorbic acid) did not show correlation with reducing power activity with $r^{2}<0.3$. Furthermore, total polyphenol or total flavonoid content was not highly correlated with superoxide radical scavenging activity $\left(r^{2}=0.520\right.$ and 0.667 , respectively).

\section{Antimicrobial activity}

Antibacterial activities of fermented Camellia japonica leaf extracts were assayed in vitro by agar disc diffusion against four bacterial species. Table 4 summarizes results of microbial growth inhibition by methanol or ethanol extract of fermented Camellia japonica leaves. Antimicrobial activities of both extracts were concentration-dependent (Table 4).

Ethanol extract showed higher antimicrobial activities against both Gram-positive and Gramnegative bacteria than methanol extract. Ten micrograms of ampicillin (positive control) showed wide zones of inhibition against all test organisms (7.0-8.7 mm). DMSO negative control showed no zone of inhibition (Table 4).

Table 2: $I_{50}$ values of antioxidant activity of Camellia japonica fermented leaf extracts

\begin{tabular}{|c|c|c|c|c|c|c|}
\hline \multirow{3}{*}{ Solvent } & \multicolumn{4}{|c|}{$\mathrm{IC}_{50}(\mathrm{mg} / \mathrm{mL})$} & \multirow{3}{*}{$\begin{array}{c}\text { Chelating } \\
\text { activity on } \\
\text { ferrous ions }\end{array}$} & \multirow{3}{*}{$\begin{array}{c}\text { Reducing } \\
\text { power } \\
\text { activity }\end{array}$} \\
\hline & \multicolumn{4}{|c|}{ Radical scavenging activity } & & \\
\hline & DPPH & Superoxide & $\begin{array}{c}\text { Hydrogen } \\
\text { peroxide }\end{array}$ & Nitric oxide & & \\
\hline $100 \% \mathrm{MeOH}$ & $0.23 \pm 0.004$ & $0.33 \pm 0.03$ & $0.36 \pm 0.01$ & $0.35 \pm 0.01$ & $0.28 \pm 0.04$ & $0.46 \pm 0.05$ \\
\hline $70 \% \mathrm{EtOH}$ & $0.22 \pm 0.003$ & $0.23 \pm 0.02$ & $0.28 \pm 0.01$ & $0.35 \pm 0.01$ & $0.21 \pm 0.03$ & $0.47 \pm 0.06$ \\
\hline
\end{tabular}

$\mathrm{IC}_{50}$ was obtained by interpolation from linear regression analysis. Each value is expressed as mean \pm standard deviation $(n=3)$. "Data are statistically different from the value of methanol extract $(p<0.05)$

Table 3: Coefficients of correlation between antioxidant compounds and antioxidant activities of methanol and ethanol extracts of the fermented Camellia japonica leaves

\begin{tabular}{lcccccc}
\hline Antioxidant & DPPH & Superoxide & $\begin{array}{c}\text { Hydrogen } \\
\text { peroxide }\end{array}$ & Nitric oxide & $\begin{array}{c}\text { Chelating } \\
\text { effect on } \\
\text { ferrous ions }\end{array}$ & Reducing power \\
\hline $\begin{array}{l}\text { Total } \\
\text { polyphenol }\end{array}$ & $0.943^{*}$ & 0.520 & $0.994^{*}$ & $0.959^{*}$ & $0.999^{*}$ & 0.002 \\
$\begin{array}{l}\text { Total } \\
\text { flavonoid }\end{array}$ & $0.996^{*}$ & 0.667 & $0.969^{*}$ & $0.997^{*}$ & $0.933^{*}$ & 0.271 \\
$\begin{array}{l}\text { Total } \\
\text { carotenoid }\end{array}$ & 0.761 & 0.254 & $0.891^{*}$ & 0.796 & $0.941^{*}$ & 0.299 \\
$\begin{array}{l}\text { L-Ascorbic } \\
\text { acid }\end{array}$ & $0.814^{*}$ & 0.279 & $0.922^{*}$ & $0.855^{*}$ & $0.964^{*}$ & 0.196 \\
\hline
\end{tabular}

All values are absolute value of correlation coefficients; $p<0.05$ is considered statistically significant 
Table 4: Antimicrobial activities of extracts of fermented Camellia japonica leaves against S. epidermidis, $B$. subtilis subsp., K. pneumoniae and E. coli

\begin{tabular}{|c|c|c|c|c|c|}
\hline \multirow[b]{2}{*}{ Antimicrobial } & & \multicolumn{4}{|c|}{ Inhibitory zone (diameter, mm) } \\
\hline & & $\begin{array}{c}\text { S. } \\
\text { epdermidis }\end{array}$ & $\begin{array}{l}\text { B. } \\
\text { subtilis } \\
\text { subsp. }\end{array}$ & K. pneumoniae & E. coli \\
\hline $\begin{array}{l}\text { Ampicillin }(10 \mu \mathrm{g}) \\
\text { (positive control) }\end{array}$ & & $8.7 \pm 0.29^{*}$ & $8.7 \pm 0.29^{*}$ & $7.0 \pm 0.01^{*}$ & $8.2 \pm 1.04$ \\
\hline $\begin{array}{l}\text { DMSO } \\
\text { (negative control) }\end{array}$ & & - & - & - & - \\
\hline & $4 \mathrm{mg}$ & $0.3 \pm 0.29$ & - & $0.3 \pm 0.58$ & $0.2 \pm 0.29$ \\
\hline $100 \% \mathrm{MeOH}$ & $\begin{array}{c}8 \mathrm{mg} \\
16 \mathrm{mg}\end{array}$ & $\begin{array}{l}1.0 \pm 0.50 \\
3.3 \pm 0.58\end{array}$ & $\begin{array}{l}0.8 \pm 0.29 \\
3.5 \pm 0.50\end{array}$ & $\begin{array}{l}1.5 \pm 0.50 \\
3.5 \pm 0.50\end{array}$ & $\begin{array}{l}1.3 \pm 0.58 \\
2.8 \pm 1.15\end{array}$ \\
\hline $70 \% \mathrm{EtOH}$ & $\begin{array}{c}4 \mathrm{mg} \\
8 \mathrm{mg} \\
16 \mathrm{mg} \\
\end{array}$ & $\begin{array}{l}0.8 \pm 0.29 \\
1.7 \pm 0.58 \\
3.7 \pm 0.58 \\
\end{array}$ & $\begin{array}{c}- \\
1.7 \pm 0.58 \\
3.7 \pm 0.58 \\
\end{array}$ & $\begin{array}{l}0.5 \pm 0.50 \\
1.8 \pm 0.58 \\
4.0 \pm 0.87\end{array}$ & $\begin{array}{l}0.3 \pm 0.29 \\
1.7 \pm 0.29 \\
4.2 \pm 0.76 \\
\end{array}$ \\
\hline
\end{tabular}

Each value is expressed as mean \pm standard deviation $(n=3)$. Data are statistically different from the value of DMSO (negative control) $(p<0.05)$

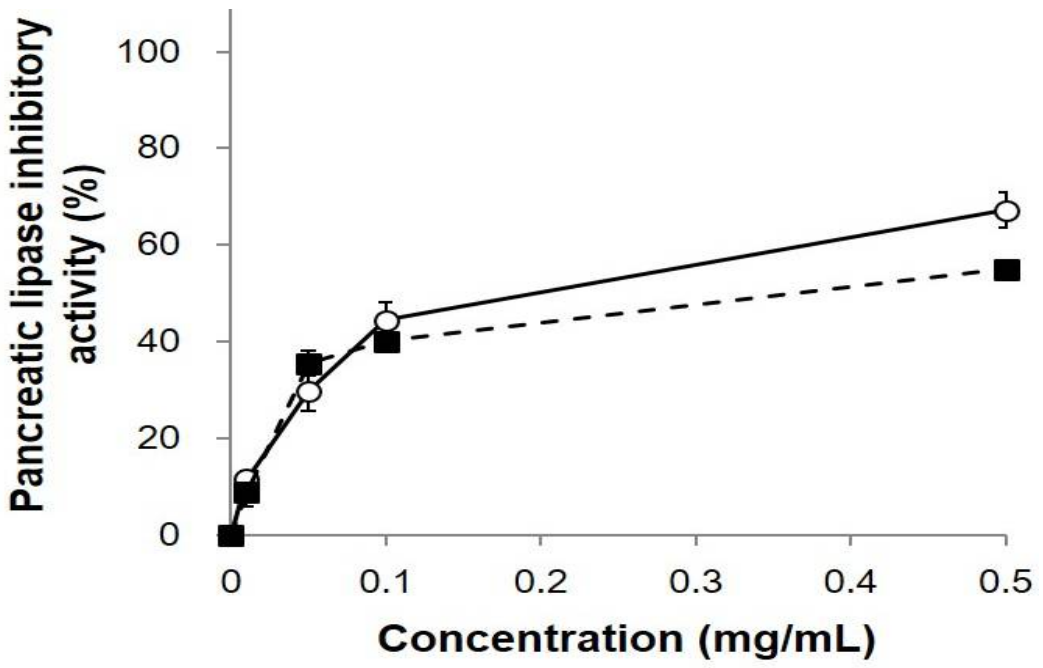

Figure 1: Pancreatic lipase inhibitory activity of methanol (o) and ethanol ( $\mathbf{a})$ extracts of fermented Camellia japonica leaves. Each value is expressed as mean \pm standard deviation $(n=3)$. "Data are statistically different from the value for ethanol extract $(p<0.05)$.

\section{Pancreatic lipase inhibition activity}

In the current study, methanol and ethanol extracts of the fermented Camellia japonica leaves inhibited the lipase activity in a dosedependent manner in the assay system with $\mathrm{p}$ NPB as a substrate (Figure 1). Methanol extract showed higher activity than ethanol extract $(p<$ 0.05). Methanol extract showed significantly higher lipase inhibition effect $\left(\mathrm{IC}_{50}=0.308\right.$ $\mathrm{mg} / \mathrm{mL})$ than ethanol extract $\left(\mathrm{IC}_{50}=0.397\right.$ $\mathrm{mg} / \mathrm{mL}$ ) (Figure 1) $(p<0.05)$. Nevertheless, its activity was weak $\left(\mathrm{IC}_{50}\right.$ value of $\left.0.308 \mathrm{mg} / \mathrm{mL}\right)$ than that of hesperidin $\left(\mathrm{IC}_{50}\right.$ value of 0.032 $\mathrm{mg} / \mathrm{mL}$ ), the positive control.

\section{DISCUSSION}

Nuruk is a dry cake of wheat, barley, and rice that hosts a variety of wild yeasts, bacteria, and koji mold spores. It is useful for saccharification of starch during fermentation [20].

In the current study, amounts of total phenolics (32274 mg/100 g) and flavonoids (20519 mg/100 g) in ethanol extract of fermented Camellia japonica leaves were higher than those in methanol extract (Table 1). This indicates that ethanol is a relatively more efficient extraction solvent for polyphenolic compounds from fermented Camellia japonica leaves. In a previous study, ethanol extracts of pu-erh tea fermented by $M$. pilosus contained 12500 $\mathrm{mg} / 100 \mathrm{~g}$ of total phenolics [21]. In the present study, $70 \%$ ethanol extract contained phenolic compound of $32274 \mathrm{mg} / 100 \mathrm{~g}$ (Table 1). Phenolic compounds are aromatic secondary plant metabolites. They mainly include flavonoids, carotenoids, and L-ascorbic acid with high antioxidant activity. Their consumption has 
been linked to decreased risk of chronic and degenerative diseases [22].

Results from superoxide- and hydrogen peroxide-scavenging activity and metal chelation assay revealed that fermented Camellia japonica leaf extracts could act as antioxidants (Table 2). Moreover, high correlations between antioxidant capacities and total phenolic and flavonoid contents of fermented Camellia japonica leaf extracts were observed (Table 3). The antioxidant activity of phenolics is mainly due to their redox properties which make them act as reducing agents, hydrogen donors, and singlet oxygen quenchers. They may also have metal chelating potential [23].

Some commercial antibiotics used today have unwanted side effects or antimycotic resistance [24]. Thus, there is a need to search for natural products with antimicrobial activity. Plants remain the most common source of antimicrobial agents [25]. Many aromatic plants have been used traditionally in folk medicine as well as in food preservatives to extend shelf life and improve the safety of food by inhibiting the growth of bacteria, fungi, and yeast [25]. In the present study, fermented Camellia japonica leaf extracts had antimicrobial activity all bacteria strains tested (Table 4). In a previous study, antimicrobial effects of pu-erh tea extracts on $S$. aureus were $64 \%$, whereas those of $B$. subtilis were $50 \%$ [26]. These antimicrobial activities of tea might be affected by bacteria strains tested. Therefore, further studies are necessary to investigate antimicrobial activity of fermented Camellia japonica leaf extracts with more diverse strains.

Obesity is associated with increased risks of metabolic syndrome, diabetes mellitus, hypertension and some cancers [27]. Obesity is a common, serous, and costly health problem in developed nations, it accounts for $2-6 \%$ of total health care costs [27]. Orlistat, a potent competitive inhibitor of gastric and pancreatic lipase, has been approved by FDA as an antiobesity drug [28]. However, this medication is associated with side-effects such as intestinal flatulence, borborygmic, and abdominal cramps [28]. Therefore, searching potent lipase inhibitors from natural plant extracts might be a useful approach to treat obesity.

\section{CONCLUSION}

Camellia japonica leaves fermented with Nuruk were shown to possess potential antioxidant, antimicrobial and lipase inhibitory effects. Thus, they might have, potential in pharmaceutical and food applications. Additional studies are needed to elucidate the detailed mechanism underlying the effect of fermented Camellia japonica leaves.

\section{DECLARATIONS}

\section{Acknowledgement}

This research was supported by the 2018 scientific promotion program funded by Jeju National University.

\section{Conflict of Interest}

No conflict of interest associated with this work.

\section{Contribution of Authors}

The authors declare that this work was done by the authors named in this article and all liabilities pertaining to claims relating to the content of this article will be borne by them.

\section{REFERENCES}

1. Camargo LE, Pedroso LS, Vendrame SC, Mainardes RM, Khalil NM. Antioxidant and antifungal activities of camellia sinensis (I.) kuntze leaves obtained by different forms of production. Braz J Biol 2016; 76: 428-434

2. Wulandari RA, Amano M, Yanagita T, Tanaka T, Kouno I, Kawamura D, Ishimaru K. New phenolic compounds from camellia sinensis $I$. Leaves fermented with aspergillus sp. J Nat Med 2011; 65: 594-597

3. Zhao L, Jia S, Tang W, Sheng J, Luo Y. Pu-erh tea inhibits tumor cell growth by down-regulating mutant p53. Int J Mol Sci 2011; 12: 7581-7593

4. Kang O. Production of fermented tea with rhodotorula yeast and comparison of its antioxidant effects to those of unfermented tea. Korean J Food Cook Sci 2017; 26: 422-427

5. Chan EWC, Lim, Y. Y., Chem, Y. L. Antioxidant activity of camellia sinensis leaves and tea from a lowland plantation in Malaysia. Food Chem 2007; 102: 12141222

6. Yoon IS, Park DH, Kim JE, Yoo JC, Bae MS, Oh DS, Shim JH, Choi $C Y$, An KW. Identification of the biologically active constituents of camellia japonica leaf and anti-hyperuricemic effect in vitro and in vivo. Int $\mathrm{J}$ Mol Med 2017; 39: 1613-1620

7. Yoshikawa M, Harada E, Murakami T, Matsuda $H$, Yamahara J, Murakami N. Camelliasaponins b1, b2, c1 and $c 2$, new type inhibitors of ethanol absorption in rats from the seeds of camellia japonica I. Chem Pharm Bull (Tokyo) 1994; 42: 742-744

8. Akihisa $T$, Yasukawa $K$, Kimura $Y$, Takase $S$, Yamanouchi S, Tamura T. Triterpene alcohols from camellia and sasanqua oils and their anti-inflammatory effects. Chem Pharm Bull (Tokyo) 1997; 45: 2016-2023 
9. Onodera K, Hanashiro K, Yasumoto T. Camellianoside, a novel antioxidant glycoside from the leaves of camellia japonica. Biosci Biotechnol Biochem 2006; 70: 19951998

10. Park JC, Hur JM, Park JG, Hatano T, Yoshida T, Miyashiro H, Min BS, Hattori M. Inhibitory effects of Korean medicinal plants and camelliatannin $h$ from camellia japonica on human immunodeficiency virus type 1 protease. Phytother Res 2002; 16: 422-426

11. Thao NT, Hung TM, Lee MK, Kim JC, Min BS, Bae K. Triterpenoids from camellia japonica and their cytotoxic activity. Chem Pharm Bull (Tokyo) 2010; 58: 121-124

12. Cho HK, Lee JY, Seo WT, Kim MK, Cho KM. Quality characteristics and antioxidant effects during makgeolli fermentation by purple sweet potato-rice nuruk. Kor $J$ Food Sci Tech 2012; 44: 728-735

13. Kim MY, Kim IJ, Im SJ, Kim JH, Heo JM, Song SY, Kim $\mathrm{JH}$, Moon SH, Cho S. Polyphenols and antioxidant capacity of a spontaneous reddish mutant in satsuma mandarin, shinheungri. Nat Prod Res 2014; 28: 20362039

14. Im SJ, Kim JH, Kim MY. Evaluation of bioactive components and antioxidant and anticancer properties of citrus wastes generated during bioethanol production. Nat Prod Commun 2014; 9: 483-486

15. Talcott ST, Percival SS, Pittet-Moore J, Celoria C. Phytochemical composition and antioxidant stability of fortified yellow passion fruit (passiflora edulis). J Agric Food Chem 2003; 51: 935-941

16. Huang YC, Chang $Y H$, Shao YY. Effects of genotype and treatment on the antioxidant activity of sweet potato in taiwan. Food Chem 2006; 98: 529-538

17. Kang DH, Kim MY. Antimicrobial activity of Korean camellia mistletoe (korthalsella japonica (thunb.) engl.) extracts. Journal of Applied Pharmaceutical Science 2016; 6: 226-230

18. Elgayyar M, Draughon FA, Golden DA, Mount JR. Antimicrobial activity of essential oils from plants against selected pathogenic and saprophytic microorganisms. $J$ Food Prot 2001; 64: 1019-1024
19. Kawaguchi K, Mizuno T, Aida K, Uchino K. Hesperidin as an inhibitor of lipases from porcine pancreas and pseudomonas. Biosci Biotechnol Biochem 1997; 61: 102-104

20. Song SH, Lee C, Lee S, Park JM, Lee HJ, Bai DH, Yoon SS, Choi JB, Park YS. Analysis of microflora profile in Korean traditional nuruk. J Microbiol Biotechnol 2013; 23: $40-46$

21. Hou CW, Jeng KC, Chen YS. Enhancement of fermentation process in pu-erh tea by tea-leaf extract. $J$ Food Sci 2010; 75: H44-48

22. Robbins RJ. Phenolic acids in foods: An overview of analytical methodology. J Agric Food Chem 2003; 51: 2866-2887

23. Hossain MA, Shah $M D$, Gnanaraj $C$, lqbal $M$. In vitro total phenolics, flavonoids contents and antioxidant activity of essential oil, various organic extracts from the leaves of tropical medicinal plant tetrastigma from sabah. Asian Pac J Trop Med 2011; 4: 717-721

24. Nguyen MH, Peacock JE, Jr., Morris AJ, Tanner DC, Nguyen ML, Snydman DR, Wagener MM, Rinaldi MG, Yu VL. The changing face of candidemia: Emergence of non-candida albicans species and antifungal resistance. Am J Med 1996; 100: 617-623

25. Bibitha B, Jisha VK, Salitha CV, Mohan S, Valsa AK. Antibacterial activity of different plant extracts. Indian $J$ Microbiol 2002; 42: 361-363

26. Wu SC, Yen GC, Wang BS, Chiu CW, Yen WJ, Chang $L W$, Duh PD. Antimutagenic and antimicrobial activities of pu-erh tea. LWT- Food Sci Technol 2007; 40: 506512

27. Calle EE, Rodriguez C, Walker-Thurmond K, Thun MJ. Overweight, obesity, and mortality from cancer in a prospectively studied cohort of U.S. Adults. $N$ Engl $J$ Med 2003; 348: 1625-1638

28. James WP, Caterson ID, Coutinho W, Finer $N$, Van Gaal $L F$, Maggioni AP, Torp-Pedersen C, Sharma AM, Shepherd GM. Effect of sibutramine on cardiovascular outcomes in overweight and obese subjects. N Engl $J$ Med 2010; 363: 905-917. 